\title{
PENGARUH PEMANGKASAN TERHADAP PERTUMBUHAN DAN PRODUKSI BERBAGAI VARIETAS CABAI MERAH (Capsicum annuum L.)
}

\section{(The Effect ofPruningon the Growth and Production of Variesof Red Chilli Pepper (Capsicum annuum L))}

\author{
Sukmawati $^{1}$, St. Subaedah ${ }^{2}$ dan Sudirman Numba ${ }^{2}$ \\ ${ }^{1}$ Staf Dinas Pertanian Kabupaten Maros, Sulawesi Selatan, \\ Email : emmaandimasduki@mail.com \\ ${ }^{2}$ Jurusan Agroteknologi Fakultas Pertanian UMI, Makassar \\ Email :st.subaedah@umi.ac.id
}

\begin{abstract}
Red Chilli pepper is one kind of plant that has high economic value, because it is necessary not only for household needs, but also a need for the industry. This research was conducted at the location of Farmers Kelompok Tani Sumber Rezeki, Toddopulia Village, District Tanralili, Maros, which lasted from March to July 2016. The study aims to analyze the effect of pruning on the growth and yield of different varieties of chilli red. This study was designed by Split Plot Design. In the main plot pruning consists of two levels ie without trimming and pruning wild Shoots, as a subplot that varieties of three types: Princes variety, variety Kastilo F1variety, and Monser F1 variety. The results showed that pruning does not affect the component plant height and the number of productive branches, but a good effect on crop production with a number of fruit crops gained 135.68 fruit, fruit weight per plant was obtained $635.10 \mathrm{~g}$ of fruit weight per plot was obtained 10, $85 \mathrm{~kg}$. Weight of fruit per hectare high of 30.15 tons obtained in the interaction between pruning and varietys Princes.
\end{abstract}

Keywords: Pruning, Varieties, red chili, growth and production

\section{PENDAHULUAN}

Cabai keriting merupakan salah satu varietas cabai besar atau cabai merah (C.annum var. longom), warna buah tua kedua jenis cabai ini sama-sama merah, tetapi sosok buahnya yang berbeda. Buah cabai keriting berukuran lebih kecil dan bentuknya berlekuk - lekuk seperti mengeriting sehingga disebut cabai keriting (Setiadi, 2015).

Cabai keriting merupakan tanaman hortikultura yang banyak menarik perhatian berbagai kalangan karena sebagai menu hidangan sehari-hari masyarakat. Selain digunakan untuk keperluan rumah tangga, cabai keriting juga dapat digunakan untuk keperluan industri diantaranya, Industri makanan dan industri obat - obatan atau jamu. Buah cabai keriting ini selain dijadikan sayuran atau bumbu masakan dalam menu sehari hari, juga mempunyai potensi untuk menaikan pendapatan petani (Sunaryono, 2000).

Cabai keriting memiliki beberapa kultivar atau varietas, sampai 2006 varietas cabai keriting yang sudah dilepas oleh Menteri Pertanian RI tidak kurang dari 15 varietas unggul, baik yang diproduksi dari luar (di antaranya dari 
Thailan, Korea, Vietnam, India, Jepang) maupun dari dalam negeri (Setiadi, 2015)

Bagi masyarakat Indonesia cabai keriting tanaman perdu dengan rasa buah pedas yang disebabkan oleh kandungan kapsaicin, selain mempunyai rasa pedas yang dapat menambah selera makan. Rasa dan komposisi kimiawi buah cabai baik yang berwarna merah maupun warna lainnya, beragam menurut varietas tanaman, kondisi pertumbuhan tanaman, derajat kematangan buah dan cara pengelolaannya. Rata-rata setiap $1,80 \mathrm{~g}$ buah cabai merah mengandung energi 0,145 $\mathrm{g}$ air, 0,216 $\mathrm{g}$ protein 0,059 $\mathrm{g}$, asam lemak dan 1,019 g karbohidrat. Selain itu terkandung pula sejumlah kalsium $(2,664$ $\mathrm{mg})$.fosfor $(5,274 \mathrm{mg})$, besi $(0,140 \mathrm{mg})$, serta vitamin-vitamin seperti vitamin A (48,980 mg), B6 (0.037 mg) dan vitamin C. $(1,375 \mathrm{mg}$ ) (Indian Institute of Spices Research 2004)

Kebutuhan komoditas cabai semakin meningkat sejalan dengan makin bervariasinya jenis dan menu yang memanfaatkan produk ini (Newangsih, Imdad dan Wahyudi (1994).

Tanaman cabai keriting dapat beradaptasi luas mulai dari dataran rendah sampai ke dataran tinggi, tergantung dari varietas yang digunakan. Untuk memperoleh hasil buah yang optimal, selain dengan menggunakan varietas yang tahan terhadap OPT, juga perlu diperhatikan penerapan teknologi yang tepat.

Produktivitas cabai nasional ratarata 5,5 ton/ha (Santika, 2006). Agustin. (2010), melaporkan bahwa potensi produktivitas cabai bisa mencapai 20-40 ton/ha, namun saat ini belum banyak yang mampu mencapai potensi produksi tersebut sehingga sangat sulit sekali mencari cabai di pasaran dalam jumlah yang sesuai jumlah kebutuhan. Hal inilah yang sering menyebabkan harga cabai sangat mahal atau diatas harga normal. Rendahnya produktivitas tersebut disebabkan masih kurangnya inovasi teknologi budidaya yang diterapkan pada budidaya tanaman cabai. Oleh karena itu dibutuhkan perbaikan teknik budidaya yang dapat mengatasi masalah tersebut.

Perbaikan teknik budidaya dimulai dengan pemilihan varietas yang sesuai dan juga tindakan pemeliharaan, seperti pemangkasan perlu diperhatikan untuk memperbaiki pertumbuhan dan sekaligus meningkatkan produksi tanaman cabai baik kuantitas maupun kualitasnya.

Varietas terdiri dari sejumlah genotipe yang berbeda, dimana masing- 
masing genotipe mempunyai kemampuan menyesuaikan diri terhadap lingkungan. Setiap varietas memiliki perbedaan genetik yang dapat mempengaruhi pertumbuhan dan hasil serta kemampuan adaptasi yang berbeda-beda. Setiap varietas cabai memberikan hasil yang berbeda tergantung bagaimana cara kita melakukan perlakuan budidaya yang intensif dan baik.

Varietas adalah faktor yang sangat penting menentukan dalam pertumbuhan dan hasil tanaman selain faktor lingkungan pemilihan varietas unggul merupakan komponen teknologi yang penting untuk mencapai produksi yang tinggi. Kelebihan varietas unggul dibandingkan dengan varietas lokal adalah produksi yang tinggi, ketahanan terhadap hama dan penyakit, respons pemupukan sehingga produksi yang diperoleh baik kwalitas maupun kuantitas dapat meningkat (Soegito \& Adie 1993).

Selain varietas, pemeliharaan juga sangat penting dalam perbaikan teknik budidaya tanaman. Salah satu teknik pemeliharaan yang penting dalam budidaya cabai yaitu pemangkasan.

Pemangkasan berarti membuang bagian tanaman yang tidak diperlukan. Bagian yang dimaksud dapat berupa sulur (mentimun, melon), daun (mentimun, melon, cabai, paprika, tomat, terong), pucuk (melon), tunas air (tomat, cabai, paprika, terong, mentimun, melon), atau buah muda (melon). Pemangkasan bertujuan untuk mengefektifkan pertumbuhan dan perkembangan tanaman ke arah yang lebih produktif. Tujuan lainnya adalah untuk meningkatkan efisiensi penggunaan nutrisi (Tony, 2003),

Berdasarkan uraian di atas, maka perlu dilakukan suatu penelitian mengenai pengaruh pemangkasan dan pemilihan varietas yang tepat guna meningkatkan produksi tanaman cabai.

\section{METODE PENELITIAN}

Penelitian ini dilaksanakan di lokasi Kelompok Tani Sumber Rezeki, Dusun Sabantang Desa Toddopulia Kecamatan Tanralili Kabupaten Maros, pada Bulan Maret sampai Bulan Juli 2016. Letak wilayah penelitian berada pada posisi ketinggian $300 \mathrm{~m}$ di atas permukaan laut.

Bahan-bahan yang digunakan dalam penelitian ini adalah benih cabai keriting yang terdiri dari 3 varietas yaitu: Varietas Princes, Varietas Kastilo F1 dan Varetas Moncer F1, Pupuk Trikompos, mulsa 
plastik hitam perak.

Alat yang dugunakan adalah hand traktor, cangkul, garu, meteran, hand sprayer, gembor, timbangan analitik, timbangan duduk, jangka sorong, mistar, gunting, pisau, tali raffia, label serta alat tulis menulis yang diperlukan.

Penelitian ini menggunakan Rancangan Petak Terbagi (Split Plot Design) Petak utama adalah Pemangkasan terdiri dari 2 taraf yaitu :

$$
\begin{aligned}
\mathrm{P} 0= & \text { Tanpa pemangkasan } \\
\mathrm{P} 1= & \text { Pemangkasan tunas Air } / \\
& \text { Wiwilan }
\end{aligned}
$$

Sebagai anak petak adalah pengaruh varietas yang terdiri dari tiga jenis yaitu :

$$
\begin{aligned}
& \mathrm{V}_{1}=\text { Varietas Princes } \\
& \mathrm{V}_{2}=\text { Varietas Kastilo F1 }
\end{aligned}
$$

$$
\mathrm{V}_{3}=\text { Varietas Moncer F1 }
$$

Dengan demikian terdapat 6 kombinasi perlakuan yaitu P0V1, P0V2, P0V3 dan P1V1, P1V2, P1V3, setiap kombinasi perlakuan diulang 3 kali sehingga terdapat 18 unit percobaan,

Adapun peubah yang diamati meliputi tinggi tanaman, jumlah cabang, jumlah buah pertanaman, dan produksi perhektar.

\section{HASIL DAN PEMBAHASAN}

\section{Tinggi Tanaman}

Hasil analisis data menunjukkan bahwa terdapat pengaruh interaksi antara pemangkasan dengan varietas terhadap tinggi tanaman cabai keriting pada umur 56 hari setelah tanam (HST).

Tabel 1. Rata-rata tinggi tanaman berbagai varietas cabai keriting dengan Perlakuan pemangkasan umur 56 HST.

\begin{tabular}{lcc}
\hline \multicolumn{1}{c}{ Perlakuan } & Tinggi tanaman & NP BNT \\
$(\mathbf{c m})$ & $\mathbf{5 \%}$ \\
\hline P0V1 ( Tanpa Pemangkasan Varietas Princes) & $93,67^{\mathrm{ab}}$ & 16,25 \\
P0V2 (Tanpa Pemangkasan Varietas Kastilo F1) & $84,00^{\mathrm{b}}$ & \\
P0V3 ( Tanpa Pemangkasan Varietas Monser F1) & $91,6^{\mathrm{ab}}$ \\
P1V1 ( Pemangkasan Varetas Princes) & $103,42^{\mathrm{a}}$ & \\
P1V2 (Pemangkasan Varietas Kastilo F1) & $95,08^{\mathrm{ab}}$ & \\
P1V3 ( Pemangkasan Varietas Monser F!) & $87,50^{\mathrm{ab}}$ \\
\hline
\end{tabular}
BNT pada taraf $a=0,05$.

Hasil uji lanjut BNT pada Tabel 1 yang tertinggi yaitu 103,42 cm, namun menunjukkan bahwa interaksi antara tidak berbeda nyata dengan interaksi perlakuan pemangkasan denganvarietas lainnya, tetapi berbeda nyata dengan Princes (P1VI) diperoleh tanaman cabe interaksi antara perlakuan tanpa 
pemangkasan dengan varietas Kastilo1 pengaruh intraksi yang nyata antara (P0V2) dengan tinggi tanaman yang perlakuan pemangkasan dan varietas diperoleh $84,00 \mathrm{~cm}$. terhadap jumlah cabang produktif.

\section{Jumlah Cabang Produktif}

Hasil pengamatan Jumlah Cabang

Produktif menunjukkan bahwa terdapat

Tabel 2. Pengaruh jumlah cabang terhadap berbagai Varietas tanaman cabai keriting dengan perlakuan pemangkasan umur 42 HST.

\begin{tabular}{lcc}
\hline \multicolumn{1}{c}{ Perlakuan } & $\begin{array}{c}\text { jumlah } \\
\text { cabang(tangkai) }\end{array}$ & $\begin{array}{c}\text { NP BNT } \\
\mathbf{5 \%}\end{array}$ \\
\hline P0V1 (Tanpa Pemangkasan Varietas Princes) & $34,83^{\text {de }}$ & 2,21 \\
P0V2 (Tanpa Pemangkasan Varietas Kastilo F1) & $31,42^{\mathrm{e}}$ \\
P0V3 ( Tanpa Pemangkasan Varietas Monser F1) & $37,58^{\mathrm{bc}}$ \\
P1V1 ( Pemangkasan Varietas Princes) & $57,08^{\mathrm{a}}$ \\
P1V2 (Pemangkasan Varietas Kastilo F1) & $38,25^{\mathrm{b}}$ \\
P1V3 (Pemangkasana Varietas Monser F1) & $35,50^{\text {cd }}$ \\
\hline Keterangan : Niai ratatatate
\end{tabular}

Keterangan : Nilai rata-rata yang diikuti oleh huruf (a,b) yang berbeda berarti berbeda nyata berdasarkan uji BNT pada taraf $a=0,05$

Tabel 2 menunjukkan bahwa interaksi antara perlakuan pemangkasan dengan varietas Princes (P1V1) diperoleh jumlah cabang produktif yang tertinggi yaitu 57,08 dan berbeda nyata dengan interaksi lainnya. Sedangkan perlakuan tanpa pemangkasan dan interaksinya dengan varietas Kastilo F1 diperoleh jumlah cabang produktif terndah yaitu 31,42 cabang.

\section{Jumlah buah pertanaman}

Hasil pengamatan jumlah buah pertanaman (pemanenan dilakuan 7 kali) menunjukkan bahwa terjadi intraksi antara perlakuan pemangkasan dan varietas cabai keriting. Uji lanjut BNT pada Tabel 3 menunjukkan bahwa interaksi perlakuan pemangkasan dengan varietas Princes (P1V1) diperoleh jumlah buah pertanaman yang terbanyak yaitu 135,68 buah dan berbeda nyata dengan interaksi lainnya. 
Tabel 3. Rata-rata jumlah buah pertanaman dengan perlakuan pemangkasan terhadap berbagai varietas cabai kriting selama 7 kali panen

\begin{tabular}{lcc}
\hline \multicolumn{1}{c}{ Perlakuan } & Jumlah buah (biji) & NP BNT \\
& & $\mathbf{5 \%}$ \\
\hline P0V1 ( Tanpa Pemangkasan Varietas Princes) & $99,75^{\mathrm{b}}$ & 9,12 \\
P0V2 (Tanpa Pemangkasan Varietas Kastilo F1) & $89,80^{\mathrm{c}}$ & \\
P0V3 (Tanpa Pemangkasan Varietas Monser F1) & $97,85^{\mathrm{bc}}$ & \\
P1V1 (Pemangkasan Varietas Princes) & $135,68^{\mathrm{a}}$ & \\
P1V2 ( Pemangkasan Varietas Kastilo F1) & $90,25^{\mathrm{c}}$ & \\
P1V3 (Pemangkasan Varietas Monser F1) & $93,32^{\mathrm{bc}}$ & \\
\hline
\end{tabular}

Keterangan : Nilai rata-rata yang diikuti oleh huruf yang berbeda berarti berbeda nyata berdasarkan uji BNT pada taraf $a=0,05$.

\section{Bobot Buah per Petak}

Hasil pengamatan bobot buah perpetak (7 kali panen) menunjukkan bahwa terjadi intraksi antara perlakuan pemangkasan dan varietas cabai keriting terhadap Bobot buah perpetak. Pada interaksi lainnya.

Tabel 4. Rata-rata bobot buah Perpetak dengan Pengaruh pemangkasan terhadap berbagai varietas cabai keriting.

\begin{tabular}{lcc}
\hline \multicolumn{1}{c}{ Perlakuan } & Bobot perpetak (kg) & NP BNT \\
& & $\mathbf{5 \%}$ \\
\hline P0V1 (Tanpa Pemangkasan Varietas Princes) & $7,08^{\mathrm{bc}}$ & 1,65 \\
P0V2 (Tanpa Pemangkasana Varietas Kastilo F1) & $7,24^{\mathrm{b}}$ & \\
P0V3 (Tanpa Pemangkasan Varietas Moncer F I) & $6,45^{\mathrm{bc}}$ & \\
P1V1 (Pemangkasan Varietas Princes) & $10,85^{\mathrm{a}}$ & \\
P1V2 (Pemangkasan Varietas Kastilo F I) & $5,92^{\mathrm{bc}}$ & \\
P1V3 (Pemangkasana Varietas Moncer F1) & $5,58^{\mathrm{c}}$ & \\
\hline
\end{tabular}

Keterangan : Nilai rata-rata yang diikuti oleh huruf yang berbeda berarti berbeda nyata berdasarkan uji BNT pada taraf $\mathrm{a}=0,05$.

\section{Produksi buh perhektar}

Analisis data terhadap produksi buah perhektar menunjukkan bahwa terjadi intraksi antara perlakuan pemangkasan dan varietas cabai keriting. Uji BNT pada Tabel 5 menujukkan bahwa interaksi antara pemangkasan dengan varietas

Tabel 4 disajikan hasil uji lanjut BNT yang menunjukkan bahwa pemangkasan varietas Princes (P1V1) diperoleh rata-rata bobot buah perpetak tertinggi yaitu 10,85 $\mathrm{kg}$ per petak dan berbeda nyata dengan

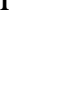


Sukmawati : Pengaruh Pemangkasan terhadap Pertumbuhan dan Produksi berbagai Varietas Cabai Merah ( Capsicum annum L.)

\begin{tabular}{lcc}
\hline \multicolumn{1}{c}{ Perlakuan } & $\begin{array}{c}\text { Bobot perhektar } \\
\text { (ton) }\end{array}$ & $\begin{array}{c}\text { NP BNT } \\
\mathbf{5 \%}\end{array}$ \\
\hline P0V1 (Tanpa Pemangkasan Varietas Princes) & $19,66^{\mathrm{bc}}$ & 4,58 \\
P0V2 (Tanpa Pemangkasan Varietas Kastilo F.I) & $20,12^{\mathrm{b}}$ & \\
P0V3 (Tanpa Pemangkasan Varietas Monser FI) & $17,92^{\mathrm{bc}}$ & \\
P1V1 ( Pemangkasan Varietas Princes) & $30,15^{\mathrm{a}}$ & \\
P1V2 (Pemangkasan Varietas Kastilo F!) & $16,45^{\mathrm{bc}}$ & \\
P1V3 (Pemangkasan Varietas Monser (F1) & $15,49^{\mathrm{c}}$ & \\
\hline Keterangan : Nilai rata-rata yang diikuti oleh huruf yang & berbeda berarti & berbeda nyata \\
berdasarkan uji BNT pada taraf a $=0,05$ & &
\end{tabular}

Hasil penelitian menunjukan bahwa terdapat interaksi yang nyata antara pemangkasan dan varietas cabai terhadap tinggi tanaman, jumlah cabang produktif, jumlah buah dan bobot buah cabai. Dari hasil analisis uji lanjutan terlihat bahwa interaksi antara pemangkasan dengan varietas Princes diperoleh pertumbuhan (Tabel 1 dan 2) dan produksi tanaman cabai yang tertinggi (Tabel 3,4 dan 5), dengan bobot buah yang diperoleh untuk 7 kali panen sebanyak 30,15 ton per ha. Pengaruh baik dari pemangkkasan ini disebabkan karena varietas Princes memiliki pertumbuhan yang lebih cepat dan ini ditunjukkan oleh tanaman yang lebih tinggi dan paling cepat berbunga serta menghasilkan buah pun lebih cepat dengan pertumbuhan yang lebih baik (tanaman lebih tinggi) akan memungkinkan penangkapan sinar matahari lebih banyak sehingga proses fotetisintesis berjalan dengan baik, dimana tanaman cabai sangat membutuhkan sinar matahari sepanjang hidupnya. Simatupang (1997) mengemukakan bahwa untuk berhasilnya penanaman perlu digunakan varietas-varietas yang mempunyai daya adaptasi yang tinggi terhadap lingkungan, karena tingginya hasil ditentukan oleh interaksi suatu varietas dengan lingkungannya meskipun secara genetik varietas lain mempunyai potensi produksi yang baik. Selanjutnya Fauzi (2009), menyatakan bahwa tingginya produksi suatu varietas dikarenakan varietas tersebut mampu beradaptasi dengan lingkungannya.

Di samping itu adanya pengaruh pemangkasan menyebabkan penerimaan cahaya matahari kebagian daun bagian dalam lebih banyak sehingga proses fotosintesis berjalan lebih maksimal. Pemangkasan bertujuan mengurangi tunas wiwilan yang tumbuh, sehingga hasil assimilat dapat lebih banyak disimpan untuk pembentukan buah. Pembuangan cabang air (wiwilan) atau bagian tanaman 
yang sebenarnya kurang produktif adalah untuk merangsang pertumbuhan dan perkembangan untuk merangsang pertumbuhan tunas pada setiap ketiak daun, sehingga akan muncul banyak percabangan. untuk dilanjutkan menghasilkan buah, sementara dalam pertumbuhan dan perkembangan Assimilat akar mempengaruhi buahnya, assimilate (potosintesis) yang terpartisi atau terbagi kebahagian tanaman yang dapat mendukung pertumbuhan dan produksi.

Pemangkasan merangsang tunas pucuk (apeks pucuk batang) tanaman untuk segera menghasilkan bunga dan buah. Tunas yang berada dipucuk adalah pusat terbentuknya auksin. Auksin tersebut akan menyebar kebagian batang setelah dilakukan pemangkasan dan mendorong munculnya tunas lateral (Gardner, Pearce and Mitchell, 1991). Jika tunas lateralnya semakin banyak maka akan memperoleh hasil produksi yang maksimal. Pertumbuhan tunas lateral dapat menimbulkan terbentuknya cabang batang yang cukup banyak pada ketiak batang utama, sedangkan pemangkasan pucuk batang menyebabkan pertumbuhan tunas, apikal terhambat sehingga tanaman tidak terlalu tinggi dan mempunyai cabang yang banyak sehingga pembentukan bunga banyak. Dari banyaknya bunga yang tumbuh tersebut dapat diartikan sebagai adanya hasil tanaman yang baik (Wilkins 2004).

Pemangkasan juga berguna untuk mengurangi beban tanaman, sehingga keberadaan daun, ranting dan buah yang melampaui lebat dapat dikurangi, dengan begitu tanaman dapat menghasilkan buah dengan kualitas dan kuantitas yang baik. Selain mampu meperbaiki kualitas serta kuantitas tanaman buah, pemangkasan tanaman juga dapat memperbaiki kondisi lingkungan tanaman seperti kelembaban, udara, sirkulasi cahaya, angin dan suhu sehingga aktivitas proses potosintesis dapat berlangsung dengan baik normal serta produksi oksigen dari tanaman sebanyak mungkin.

\section{KESIMPULAN}

Pemangkasan tidak berpengaruh terhadap komponen tinggi tanaman, jumlah cabang produktif umur berbunga, namun berpengaruh baik terhadap produksi tanaman dengan jumlah buah pertanaman diperoleh 135,68 buah, bobot buah pertanaman diperoleh 635,10 g bobot buah perpetak diperoleh $10,85 \mathrm{~kg}$. 
Bobot buah per ha tertinggi diperoleh pada interaksi antara perlakuan pemangkasan dan varietas Princes yaitu sebanyak 30,15 ton untuk pemanenan yang dilakukan sebanyak 7 kali.

\section{DAFTAR PUSTAKA}

Agustin, 2010. Peningkatan Produksi Cabe Melalui Pemangkasan Tunas. http/bp3kseteluk1blogspot.co.id 2015. Diakses tgl 05 Mei 2015

Fauzi. 2009. Pengaruh Penggunaan Mulsa Organik Terhadap Pertumbuhan dan Produksi Beberapa Varietas Cabai Merah. Skripsi pada Fakultas Pertanian Unsyiah (Tidak dipublikasikan).

Gardner, F.P. , R.B. Pearce and R.L. Mitchell. 1991. Fisiologi Tanaman Budidaya (Terjemahan H. Susilo). Universitas Indonesia (UI-Press). 426p.

Indian Institute of Spices Research, 2004. Database of varieties. India : (15)

Nawangsih A. A., H. P. Imdad, A. Wahyudi. 2005 Cabai Hot Beauty. Penebar Swadaya. Jakarta. 128 hlm.
Santika. 2006. Agribisnis Cabai. Penebar Swadaya, Jakarta. 169 hal.

Setiadi, 2015. Bertanam Cabai di Lahan dan Pot. Penebar Swadaya. Jakarta.

Simatupang, S. $1997 . \quad$ Pengaruh Pemupukan Boraks Terhadap Pertumbuhan dan Mutu Kubis. Jurnal Hortikultura 6 (5):456-469.

Soegito dan Adie 1993.Bertanam Cabai. Penebar Swadaya. Jakarta

Sunaryono, H.HG. 2000. Budidaya Cabe Merah. Cetakan ke lima. Percetakan Sinar Baru.

Tony, H. 2003. Berkebun Hidroponik Secara Murah. Penebar Swadaya. Jakarta. 96 hlm.

Wilikins S. 2004. College Botany Universitas Of New York. 